\title{
ОПТИМІЗАЦІЯ ВИТРАТ ПІДПРИЕМСТВ МАШИНОБУДІВНОЇ ГАЛУЗІ
}

\section{ОПТИМИЗАЦИЯ РАСХОДОВ ПРЕДПРИЯТИЙ МАШИНОСТРОИТЕЛЬНОЙ ОТРАСЛИ}

\section{OPTIMIZATION OF EXPENSES OF MACHINE BUILDING INDUSTRY}

У статті досліджено витрати підприємств машинобудівної галузі на прикладі провідного підприємства України - ПАТ «Мотор Січ». Досліджено природу виникнення витрат на підприємствах машинобудівної галузі та систему управління затратами. Виконаний пошук можливих резервів зниження витрат виробництва показав, щэо резерви - це не тільки зниження збитків при використанні ресурсів, але й невикористані можливості зниження витрат. Приділено увагу скороченню розриву між досягнутим рівнем використання ресурсів та можливим рівнем, виходячи із оптимізації їх суми, щяо сприятиме покращенню виробничого потенщіалу машинобудівних підприємств та доведено на прикладі одного з провідних представників галузі «Мотор Січ». У статті було виявлено, щзо варто приділяти увагу механізму мінімізації витрат підприємства в загальній сумі чистого доходу, оскільки для ефективного використання виробничих ресурсів необхідні структурні зміни якісного характеру в сфері їх управління як складової частини управління витратами в цілому

Ключові слова: управління витратами, машинобудівна галузь, оптимізація витрат, механізм мінімізації витрат, управління ресурсами підприємства.

В статье исследованы расходы предприятий машиностроительной отрасли на примере лидирующего предприятия Украинь - АО «Мотор Сич». Исследована природа возникновения затрат на предприятиях машиностроительной отрасли и система управления затратами. Выполнен поиск возможных резервов снижения издержек производства показал, что резервы - это не только снижение убытков при использовании ресурсов, но и неиспользованные возможности снижения затрат. Уделено внимание сокращению разрыва между достигнутым уровнем использования ресурсов и возможным уровнем, исходя из оптимизации их суммы, что будет способствовать улучшению производственного потенциала машиностроительных предприятий та доказано на примере одного из ведущих представителей отрасли «Мотор Сич». В статье было определено, что сточт уделять внимание механизма минимизации расходов предприятия в общей сумме чистого дохода, поскольку для эффективного использования производственных ресурсов необходимые структурные изменения качественного характера в сфере их управления, как составной части управления затратами в целом

Ключевые слова: управление затратами, машиностроительная отрасль, оптимизация расходов, механизм минимизации затрат, управления ресурсами предприятия.

In the article the enterprises' costs of building industry were investigated and Ukrainian leading enterprise - JSC "Motor Sich»-was taken as an example. The nature of the enterprises" cost appearance and the costs system management were studied. Search for possible reserves to 
reduce production costs showed that the reserves - is not only a reduction in losses in the use of resources, but also untapped opportunities to reduce costs. Attention is paid to reducing the gap between the achieved level of resources and possible level, based on the optimization of their amount, will improve production potential engineering companies, as evidenced by the example of one of the leading representatives of the industry "Motor Sich". The paper found that the mechanism should focus on minimizing costs enterprises in total net income, since the efficient use of production resources necessary structural changes in the qualitative field of management, as part of cost management in general

Keywords: cost management, engineering industry, cost optimization, cost minimization mechanism, enterprise resource management.

Вступ. Оптимізація витрат $є$ загальновизнаним способом вдосконалення діяльності підприємства та ефективним інструментом управління його розвитком. Підприємства машинобудівної галузі в межах господарської діяльності несуть різні витрати, які умовно можна розподілити на дві групи: виробничі та невиробничі витрати підприємства. Причому 3 моменту переходу до ринкової економіки роль останньої групи витрат стрімко зростає, оскільки виробничі потужності та обсяги випуску продукції вже давно не являються об'єктивними показниками ефективності діяльності підприємства. Підприємство може постійно нарощувати виробничі потужності й при цьому працювати «на склад», не маючи припливу доходів від реалізації продукції. Розміри реальних доходів виробничого підприємства безпосередньо залежать від ефективності організації діяльності щодо реалізації виробленої продукції.

Таким чином, якщо оптимізація витрат машинобудівного підприємства $\epsilon$ одним 3 двох ключових способів максимізації прибутку та підвищення ефективності діяльності підприємства, то оптимізація невиробничих витрат підприємства має особливу важливість для вдосконалення управління підприємством, оскільки підприємство одночасно мінімізує витрати й збільшує прибутки за рахунок підвищення обсягів збуту продукції.

Аналіз складу та структури витрат підприємств машинобудівної галузі продемонстрував, що питома вага витрат на збут виробленої продукції складає в даний час більше $26 \%$ від загального розміру витрат підприємств. При цьому реальний резерв зниження комерційних витрат виробничих підприємств оцінюється на рівні зниження витрат у 2,5 рази [4].

Від ефективної діяльності підприємства та реалізації продукції залежать його можливості щодо розвитку та утримання конкурентних позицій на ринку. При цьому дослідження питань управління витратами 3 комерційної діяльності підприємств присвячена порівняно невелика кількість наукових праць та практична діяльність 3 управління витратами від комерційної діяльності виробничих підприємств є слабо вивченою.

Таким чином, оптимізаційне управління витратами машинобудівного підприємства в сучасних ринкових умовах $є$ важливим напрямком діяльності 3 управління його розвитком та стаття на дану тему $\epsilon$ актуальною й значущою для забезпечення зростання економічного потенціалу як конкретних підприємств, так і народного господарства в цілому. 
Питанням дослідження ефективної діяльності підприємств присвячені наукові праці вітчизняних вчених М.Д. Бедринець [2], В.В. Бойко, О.Ю. Будинської [3], К.В. Селезньової [6], Н.М. Фідровської [7], В.В. Шарко [8], I.A. Шейко [9], в яких досліджено теоретичні та практичні основи ефективного функціонування машинобудівних підприємств в Україні. Із зарубіжних вчених варто відзначити наукові праці Г. Я. Гольдотейна, Е.М. Короткова, Р.В. Робінсона, 3.П. Румянцевої, А.Дж. Стрикленда, А.А. Томпсона, К.Дж. Хаттена, Дж.М. Хіггінса, які присвячено дослідженням засад ефективної діяльності промислових підприємств. Автори акцентують увагу на доцільності скорочення витрат підприємства за рахунок їх оптимізації на основі прийняття оптимальних рішень, що має базуватися на відповідній техніко-економічній та аналітичній інформації щодо діяльності підприємства. В той же час деякі питання вимагають подальшого вивчення, зокрема, особливості оцінювання рівня ефективності функціонування підприємств.

Постановка завдання. Провести оцінку ефективності витрат машинобудівних підприємств України, та запропонувати напрями щодо їх оптимізації.

Результати дослідження. Машинобудівну галузь без перебільшення можна назвати основою промислового виробництва будь-якої країни. Важливість стабільного розвитку машинобудівної галузі для економіки визначається тим фактом, що протягом кількох століть машинобудівна галузь залишається єдиним постачальником капітальних ресурсів до підприємств усіх галузей. Машинобудування забезпечує будь-яке виробництво машинами та обладнанням, а населення - предметами споживання. Від ступеня розвитку машинобудування, в кінцевому підсумку, залежить стійкість та ефективність розвитку інших секторів й всієї економіки в цілому.

Машинобудівний комплекс $€$ базовою галуззю економіки та іï головним системоутворюючим елементом, що визначає стан виробничого потенціалу та обороноздатності держави, стійке функціонування всіх галузей промисловості та наповнення споживчого ринку.

Сектор машинобудування $\epsilon$ основним компонентом більшої за розміром переробної промисловості, внесок якої до валової доданої вартості у переробній промисловості становить $25 \%$ та, в свою чергу, біля $3,5 \%$ до валового внутрішнього продукту України. Він складається 3 шести підгалузей. 51\% продукції виробляється трьома підгалузями, пов'язаними 3 сектором транспорту, а саме залізничним, авіаційним/суднобудівним та автотранспортним машинобудуванням. Виробництво машин та устаткування загального призначення, а також виробництво електричного устаткування також $\epsilon$ відносно великими підгалузями машинобудування, внесок яких до загального випуску сектору машинобудування становить $27 \%$ та $16 \%$ відповідно.

Машинобудування України об'єднує 11267 підприємств, з яких 146 великих, 1834 - середніх та 9287 - малих з виробництва різноманітних 
машин та устаткування, приладів та апаратури. Державна служба статистики виділяє чотири основні складові машинобудівної галузі: виробництво комп'ютерів, електронної та оптичної продукції, виробництво електронного устаткування, виробництво машин та устаткування, не віднесених до інших угруповань, виробництво автотранспортних засобів, причепів та напівпричепів та інших транспортних засобів

Витрати машинобудівного підприємства зростають у мірі підвищення ступеня готовності продукції та в результаті сумуються. Розрахунок витрат на підприємстві здійснюється 3 урахуванням поступового наростання готовності продукції.

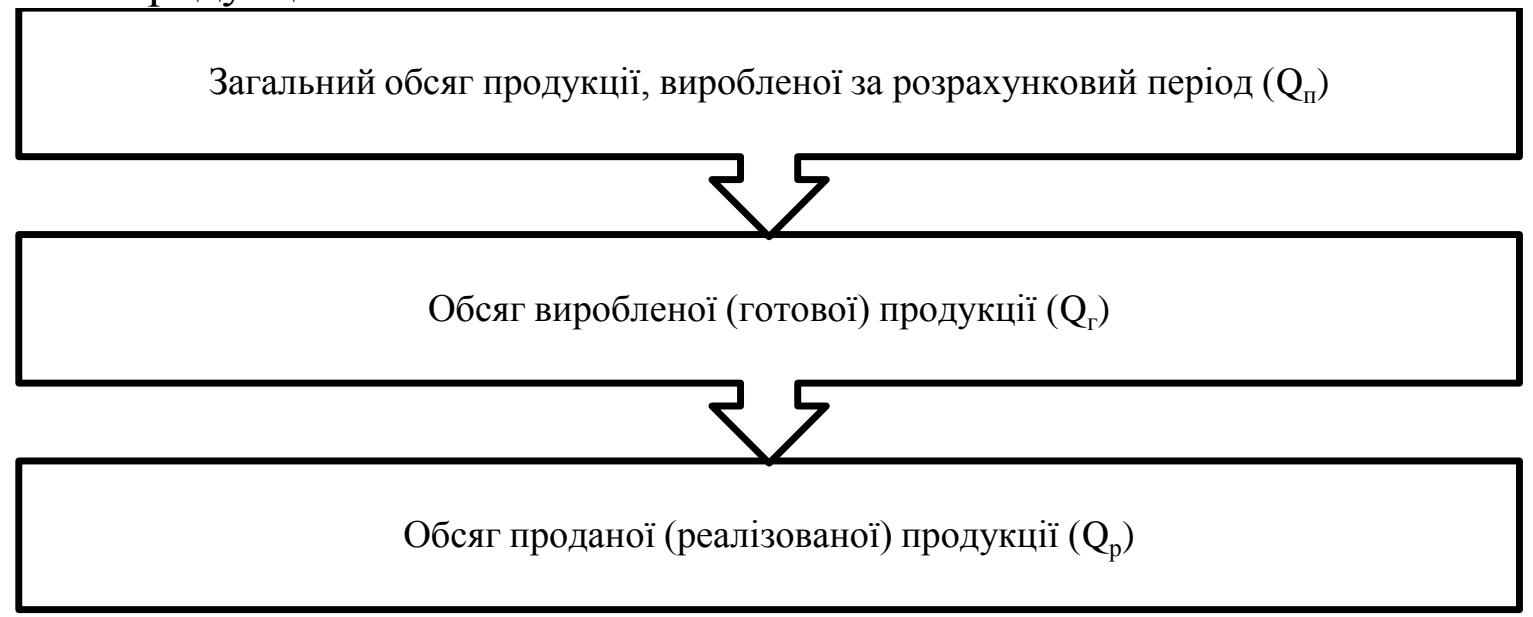

Рис. 1. Взаємозв'язок обсягів продукції та витрат за підвищенням ступеня іiі готовності

Зі схеми, представленої на рис. 1, існують винятки. Наприклад, у випадках випуску технічно простої продукції, виробничий цикл якої здійснюється в межах одного розрахункового періоду (за розрахунковий період, як правило, приймається календарний рік). У таких випадках загальний обсяг продукції, виробленої за розрахунковий період $\left(\mathrm{Q}_{n}\right)$, обсяг виробленої (готової) продукції $\left(Q_{г}\right)$ та обсяг проданої (реалізованої) продукції $\left(\mathrm{Q}_{\mathrm{p}}\right)$ будуть рівні. 3 цього випливає, що величини витрат на виробництво всього обсягу продукції, витрати на виробництво готової продукції та витрати на виробництво реалізованої продукції будуть рівні. Проте на практиці це поодинокі випадки, оскільки припускають, що виробнича діяльність починається в січні «з нуля» та повністю завершується в грудні розрахункового періоду (не залишаючи незавершеного виробництва на наступний період).

Як правило, виробнича діяльність машинобудівних підприємств має безперервний характер та супроводжується наявністю незавершеного виробництва по закінченню розрахункового періоду. Величина допустимого та необхідного обсягу незавершеного виробництва розраховується 3 врахуванням тривалості виробничого циклу випуску продукції й типу виробництва (а саме: одиничне, серійне, масове) 
Задача формування витрат полягає в такому визначенні та взаємному узгодженні впливаючих на витрати чинників, при яких заданий об'єм продукції буде вироблений з мінімальними витратами.

Базовим механізмом функціонування машинобудівного підприємства $€$ система управління, однією із основних функцій якої є управління витратами (рис. 2). Витрати підприємства - це не тільки показник, за яким визначають його прибутковість, але й індикатор, за яким при певному науковому підході можна оцінити ступінь розвитку підприємства, структуру та діапазон виробничих можливостей тощо.

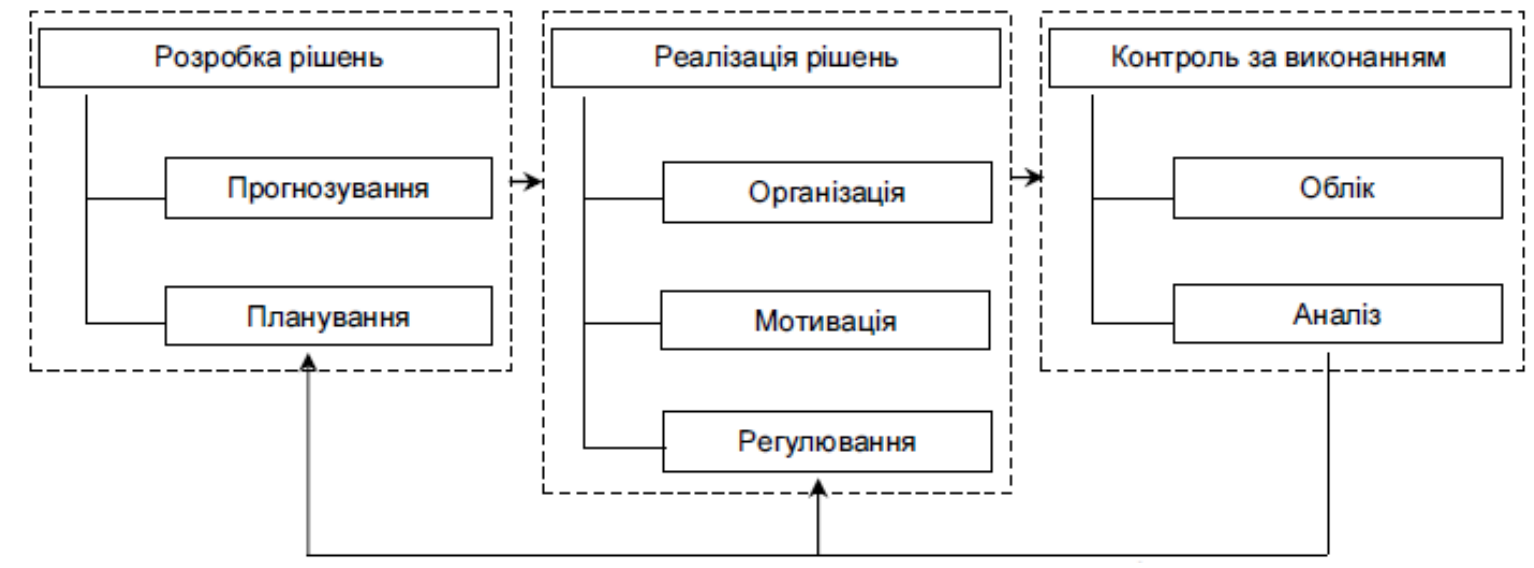

Рис. 2. Структура системи управління витратами машинобудівного підприємства

Витрати підприємства $є$ основою у формуванні його прибутку, а в сучасних ринкових умовах саме функціонування машинобудівного підприємства неможливе без системи планування та контролю витрат. Мета аналізу витрат діяльності підприємства полягає в всебічній оцінці фактичних даних, їхній оптимізації та обгрунтуванні управлінських рішень щодо подальшої раціоналізації. Аналіз здійснюється на основі принципів системного, комплексного та кібернетичного підходів. В основу системного підходу покладено дослідження об'єктів системи, розкриття їхньої цінності, виявлення багатьох типів зв'язків, зведення їх до єдиної теоретичної системи. Системний підхід до аналізу витрат передбачає [2]:

- виявлення місця та ролі показників в оцінці досягнутої ефективності виробництва;

- розроблення принципової схеми аналізу на основі класифікації факторів та резервів раціоналізації витрат;

- визначення методів вимірювання та резервів раціоналізації витрат;

- виявлення резервів раціонального використання виробничих ресурсів у поточному та перспективному плануванні собівартості.

Не менш важливим за процес аналізу витрат є процес їх прогнозування. Особливу роль відіграють чинники, пов'язані із точністю інформаційних ресурсів та повнотою забезпеченості інформацією. Сьогодні у більшості великих підприємств світу на практиці нерідко використовують інформаційні системи 3 підтримкою функції прийняття управлінських рішень на базі аналізу великої кількості інформації, у тому числі, інформації щодо витрат підприємства. Дана інформація наочно відображає стан виробничої системи 
підприємства та подається у систематизованому вигляді, що дозволяє у відносно короткі терміни приймати актуальні управлінські рішення. Тобто для забезпечення високої точності процесу прогнозування витрат підприємства їхній аналіз повинен базуватись на основних вимогах, що ставляться до інформаційного забезпечення та відповідають критеріям системності та уніфікації.

Наслідком процесу прогнозування витрат підприємства є процес їх планування, основною метою якого $є$ визначення загальної суми витрат обігу, потрібної для забезпечення нормальної роботи підприємства, 3 урахуванням наявних резервів зниження витрат на придбання, доставку, зберігання товарів та їх реалізацію. Здебільшого розрахунок планових витрат проводять згідно із запланованими заходами щодо розширення обсягів діяльності підприємства, обсягів товарообороту чи запровадження певних інноваційних рішень. Планування витрат, як складова частина системи управління витратами підприємства, є важливим, 3 точки зору можливості розрахунку майбутніх показників їх ефективності, що особливо важливо при запровадженні різного роду інноваційних рішень.

Отже, теорія витрат істотно розширює та узагальнює спеціальний технічний аспект теорії виробництва й, в свою чергу, представляє інтерес для підприємства.

Важливою складовою системи управління витратами на підприємстві $є$ розробка заходів щодо зниження витрат виробництва, що при подальшому дослідженні буде показано на прикладі підприємств машинобудівної галузі.

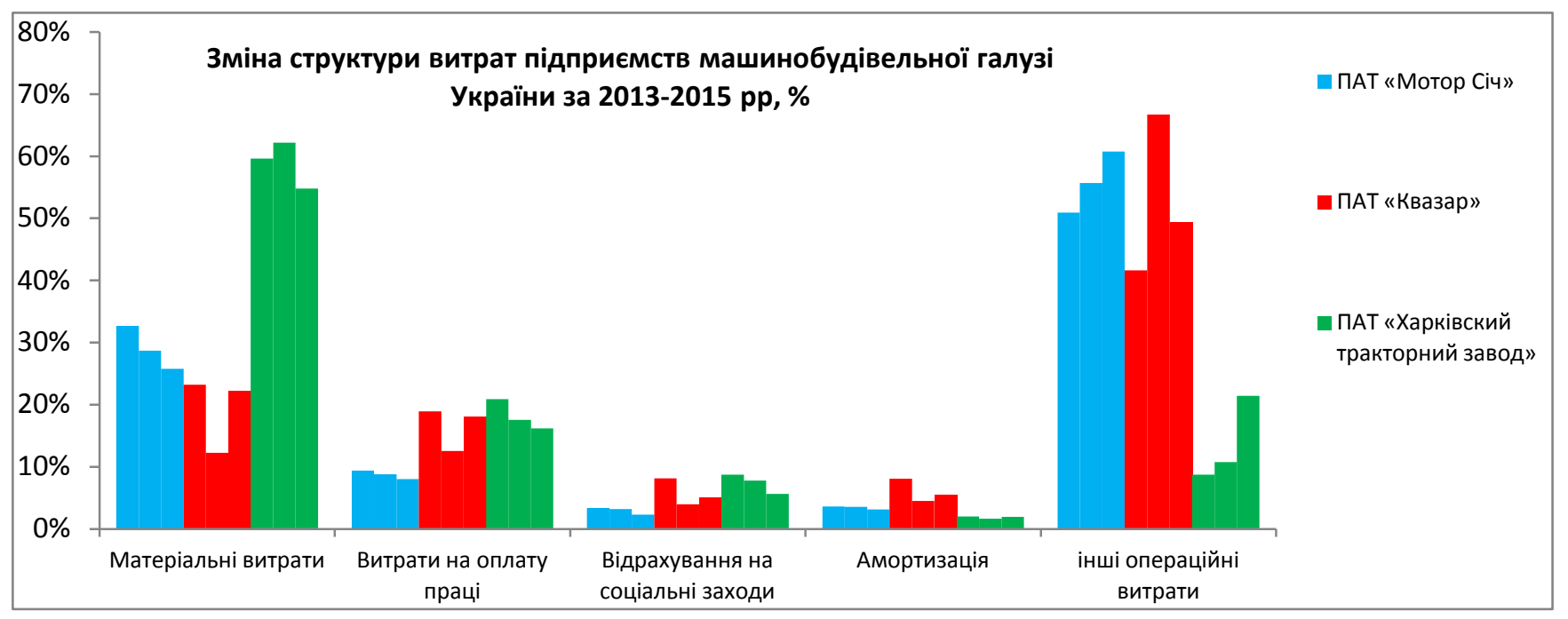

Рис 3. Структура витрат підприємств машинобудівної галузі

Перед тим, як перейти до розробки моделі оптимізації витрат на прикладі підприємства машинобудування, проаналізуємо структуру витрат провідних підприємств галузі у 2015 р. 
3 рис. 3 видно, що найбільшу вагу в структурі витрат складають операційні та матеріальні витрати. Розглянемо чинники їх зменшення на підприємствах галузі.

Для оптимізації обсягу операційних витрат доцільно зменшувати ті статті, які мають найбільшу питому вагу у загальній величині витрат. Раціональним буде мінімізація перш за все собівартості реалізації та витрат на збут (при збереженні якості машинобудівної продукції та процесу обслуговування покупців).

Для оптимізації операційних витрат, на підприємствах машинобудівної галузі, використовують:

- пошук надійних постачальників виробничих ресурсів;

- удосконалення асортименту машинобудівної продукції, що випускається;

- вдосконалення організації праці та збутової діяльності;

- підвищення продуктивності праці;

- максимальне залучення додаткових доходів від вільних активів (оренда площ, які не використовуються в даний момент суб'єктом господарювання, що принесе додатковий дохід й, таким чином, зменшить затрати на утримання цих приміщень чи обладнання);

- перманентний контроль за витратами підприємства;

- підвищення ефективності внутрішнього управління витратами на основі своєчасного та якісно проведеного аналізу.

Проблема оптимізації матеріальних витрат грунтується на: зменшенні витрат при проектуванні та розробки нової продукції; оптимізації використання металу при виробництві машинобудівної продукції.

Базою для аналізу було обрано підприємство галузі машинобудування: ПАТ «Мотор Січ».

Модель оптимізації будуватиметься на визначенні тих елементів витрат (адресати впливу), впливаючи на які, в першу чергу, можна досягти максимального ефекту від їх зменшення задля збільшення ефективності управління виробничими фондами підприємства, тобто, на проведені та застосуванні контролю та аналізу на всіх стадіях промислової діяльності підприємства машинобудування.

За результатами побудови стратегічної моделі управління витратами в процесі написання даної статті найбільша увага буде приділена групі внутрішніх заходів зниження витрат. Зокрема, в групі виробничотехнічних - раціональному використанню ресурсів виробництва; фінансових - раціональному використанню власних коштів; організаційно-управлінських - ефективному управлінню процесом виробництва в цілому.

Оскільки прибуток - мета господарської діяльності кожного підприємства, то в подальшому важливо зберегти його на тому ж рівні або навіть наростити його обсяг. Саме для цього постає необхідним знайти резерви зростання прибутку. 
Резерви зростання прибутку - це кількісно вимірні можливості його збільшення за рахунок зростання обсягу реалізації продукції, зменшення витрат на іï виробництво та реалізацію, недопущення реалізаційних збитків, вдосконалення структури вироблюваної продукції.

Вимірювання величини резервів може бути визначено шляхом порівняння досягнутого рівня витрат з їх потенційною величиною.

Важливим напрямом пошуку резервів зростання прибутку $\epsilon$ зниження витрат на виробництво та реалізацію продукції, наприклад, сировини, матеріалів, палива, енергії, амортизації основних фондів та інших витрат.

Тому, постає завдання проаналізувати структуру витрат операційної діяльності підприємств за досліджуваний період, та виділити в їх складі ті статті витрат, які, виходячи із існуючих тенденцій діяльності підприємства, можуть бути скорочені, тобто оптимізовані до певного рівня.

Для того, щоб привести витрати за статтями до порівняльного вигляду, перерахуємо їх на 1 грн. реалізованої продукції (чистого доходу від реалізації), та знайдемо таким чином мінімальний рівень витрат періоду.

Таблиия 1

Розрахунок рівня витрат на 1 грн. чистого доходу ПАТ «Мотор Січ»

\begin{tabular}{|c|c|c|c|c|c|c|c|c|c|}
\hline \multirow[t]{3}{*}{ Стаття } & \multicolumn{8}{|c|}{ Рік } & \multirow{3}{*}{$\begin{array}{c}\text { Мінімальни } \\
\text { й рівень } \\
\text { витрат }\end{array}$} \\
\hline & \multicolumn{2}{|c|}{2013} & \multicolumn{2}{|c|}{2014} & \multicolumn{2}{|c|}{2015} & \multicolumn{2}{|c|}{2016} & \\
\hline & тис.грн & $\begin{array}{c}\text { рівень } \\
\text { витра } \\
\text { т на } 1 \\
\text { грн. } \\
\text { Чд }\end{array}$ & тис.грн & $\begin{array}{c}\text { рівень } \\
\text { витрат на } 1 \\
\text { грн. ЧД }\end{array}$ & $\begin{array}{c}\text { тис.гр } \\
\text { н }\end{array}$ & $\begin{array}{c}\text { рівень } \\
\text { витра } \\
\text { т на 1 } \\
\text { грн. } \\
\text { чД }\end{array}$ & тис.грн & $\begin{array}{c}\text { рівень } \\
\text { витра } \\
\text { т на 1 } \\
\text { грн. } \\
\text { Чд }\end{array}$ & \\
\hline $\begin{array}{c}\text { Чистий } \\
\text { дохід } \\
\text { (виручка) } \\
\text { від } \\
\text { реалізації } \\
\text { продукції }\end{array}$ & 24725,7 & - & 35404,8 & - & $\begin{array}{c}33047 \\
0\end{array}$ & - & 44286,0 & - & - \\
\hline $\begin{array}{c}\text { Собівар- } \\
\text { тість } \\
\text { реалізо- } \\
\text { ваної } \\
\text { продукції }\end{array}$ & 20648,1 & $\begin{array}{c}0,835 \\
1\end{array}$ & 29890,0 & 0,8442 & $\begin{array}{c}28510 \\
0\end{array}$ & $\begin{array}{c}0,862 \\
7\end{array}$ & 33928,0 & $\begin{array}{c}0,766 \\
1\end{array}$ & 0,7661 \\
\hline $\begin{array}{l}\text { Адміні- } \\
\text { стративні } \\
\text { витрати }\end{array}$ & 1040,6 & $\begin{array}{l}0,042 \\
1\end{array}$ & 1091,7 & 0,0308 & 1453,0 & $\begin{array}{l}0,044 \\
0\end{array}$ & 2849,0 & $\begin{array}{c}0,064 \\
3\end{array}$ & 0,0308 \\
\hline $\begin{array}{c}\text { Витрати } \\
\text { на збут }\end{array}$ & 733,8 & $\begin{array}{l}0,029 \\
7\end{array}$ & 776,9 & 0,0219 & 1007,0 & $\begin{array}{l}0,030 \\
5\end{array}$ & 1393,0 & $\begin{array}{c}0,031 \\
5\end{array}$ & 0,0219 \\
\hline $\begin{array}{c}\text { Інші } \\
\text { операцій- } \\
\text { ні } \\
\text { витрати } \\
\end{array}$ & 673 & 0,027 & 870 & 0,024 & 1357 & 0,030 & 5415 & 0,122 & 0,0024 \\
\hline $\begin{array}{c}\text { Матеріальні } \\
\text { витрати } \\
\end{array}$ & 432 & $\begin{array}{l}0,017 \\
5 \\
\end{array}$ & 448 & 0,0101 & 575 & 0,013 & 643 & $\begin{array}{l}0,014 \\
5\end{array}$ & 0,013 \\
\hline Витрати на & 123 & 0,005 & 137 & 0,0031 & 179 & 0,004 & 180 & 0,004 & 0,004 \\
\hline
\end{tabular}




\begin{tabular}{|c|c|c|c|c|c|c|c|c|c|}
\hline оплату праці & & 0 & & & & & & 1 & \\
\hline $\begin{array}{c}\text { Відрахуванн } \\
\text { я на } \\
\text { соціальні } \\
\text { заходи }\end{array}$ & 44 & $\begin{array}{l}0,001 \\
8\end{array}$ & 49 & 0,0011 & 51 & 0,001 & 50,4 & $\begin{array}{l}0,001 \\
1\end{array}$ & 0,001 \\
\hline Амортизація & 475 & $\begin{array}{l}0,019 \\
2\end{array}$ & 559 & $\begin{array}{l}0,01262249 \\
9\end{array}$ & 702 & 0,016 & 861 & $\begin{array}{l}0,019 \\
4\end{array}$ & 0,0192 \\
\hline $\begin{array}{l}\text { Разом } \\
\text { витрат }\end{array}$ & $\begin{array}{c}48895 \\
2\end{array}$ & 0,977 & $\begin{array}{c}69226 \\
4\end{array}$ & 0,948 & 66881 & 1,00 & $\begin{array}{c}89605 \\
4\end{array}$ & 1,02 & 0,8 \\
\hline
\end{tabular}

Розрахований мінімальний рівень витрат має слугувати підприємству тією відправною точкою, в якій постає можливим зменшення рівня витрат на 1 грн. чистого доходу при плануванні витрат у 2017 році. Таким чином, по даним витратам операційної діяльності підприємства існують резерви їх зниження за рахунок зменшення адміністративних витрат, витрат на збут, інших операційних витрат. Тобто, ці статті витрат у розрахунку на 1 грн. чистого доходу у 2016 році значно перевищували рівень попередніх періодів, відповідно, можна говорити про їх перевитрачання.

Досягти оптимального рівня витрат ПАТ «Мотор січ» у 2016 році вдалося лише за статтею собівартість реалізованої продукції, за іншими статтями наявне перевитрачання ресурсів підприємства, тобто існує резерв зниження витрат, що в загальній сумі складає - 3737,8 тис. грн.

Таблиия 2

Прогнозування витрат ПАТ «Мотор Січ» на 2017 р. та визначення їх оптимального рівня для 2016 р., тис.грн

\begin{tabular}{|l|l|l|l|l|l|l|}
\hline Стаття & $\begin{array}{l}2014 \text { p., } \\
\text { тис. } \\
\text { грн.. }\end{array}$ & $\begin{array}{l}2015 \text { р. } \\
\text { тис. } \\
\text { грн.. }\end{array}$ & $\begin{array}{l}\text { Факт } \\
2016 \text { p. } \\
\text { тис. грн.. }\end{array}$ & $\begin{array}{l}\text { Оптимальний } \\
2016 \text { р, тис. } \\
\text { грн.. }\end{array}$ & $\begin{array}{l}\text { Економія / } \\
\text { перевитрачання } \\
\text { 2016р., тис. } \\
\text { грн.. }\end{array}$ & $\begin{array}{l}\text { Прогно3 } \\
2017 \mathrm{p.} \\
\text { тис. грн.. }\end{array}$ \\
\hline Собівартість & 29890,0 & 28510,0 & 33928 & 33928 & - & 41203,2 \\
\hline $\begin{array}{l}\text { Адміністративні } \\
\text { витрати }\end{array}$ & 1091,7 & 1453,0 & 2849 & 1365,6 & $-1483,4$ & 1658,4 \\
\hline Витрати на збут & 776,9 & 1007,0 & 1393 & 971,8 & $-421,2$ & 1180,2 \\
\hline $\begin{array}{l}\text { Інші операційні } \\
\text { витрати }\end{array}$ & 870 & 1357 & 5415 & 673 & -4742 & 4832 \\
\hline Матеріальні витрати & 448 & 575 & 643 & 432 & -211 & 598 \\
\hline $\begin{array}{l}\text { Витрати на оплату } \\
\text { праці }\end{array}$ & 137 & 179 & 180 & 123 & -57 & 182 \\
\hline $\begin{array}{l}\text { Відрахування } \\
\text { соціальні заходи }\end{array}$ & 49 & 51 & 50,4 & 44 & $-6,4$ & 50,96 \\
\hline Амортизація & 559 & 702 & 861 & 475 & -386 & 835 \\
\hline Разом витрат & 69226,4 & 66881 & 45319,4 & 38012,4 & -7307 & 50539,8 \\
\hline
\end{tabular}

За даними табл. 2 бачимо, що фактичні витрати 2016 року становлять - 45319,4 тис. грн., натомість оптимальні складають - 38012,4 тис. грн., тож підприємство не ефективно використало свої фінансові ресурси. 
Спрогнозуємо оптимальний рівень витрат на 2017 рік знаючи їх мінімальний рівень на 1 грн. чистого доходу та плановий рівень чистого доходу із врахуванням його середнього коефіцієнту зростання за аналізований період, який складає 1,214 пунктів: $44286 * 1,214=53782,3$ тис. грн. Отже, очікуваний чистий дохід на 2017 рік становить близько 53782,3 тис. грн. Таким чином, виходячи із планового чистого доходу, який зростає, має відбутися й зростання собівартості продукції на 7275,2 тис. грн. Прогнозний обсяг собівартості в загальній сумі дорівнюватиме 41203,2 тис. грн. Зауважимо, що у 2017 році за прогнозами має відбутися лише зростання витрат за собівартістю реалізованої продукції, оскільки вони напряму пов'язані зі зміною виручки від реалізації, а в нашому випадку очікується збільшення виручки у 2017 році. Інші статті витрат на 2017 рік ми оптимізуємо за критерієм мінімального рівня витрат у чистому доході. Зокрема, у 2017 році скоротилися адміністративні витрати, витрати на збут й інші операційні витрати на 1190,6, 212,8 та 4742 тис. грн. відповідно, порівняно із 2016 роком.

Варто відмітити, що керівництву підприємства потрібно приділити особливу увагу статті інші операційні витрати, оскільки за останній рік їх сума значно зросла. Це може бути наслідком знецінення запасів, псування цінностей, списання та уцінки активів, сума фінансових санкцій тощо.

В результаті проведених оптимізаційних заходів, все це призведе до підвищення фінансового результату від операційної діяльності ПАТ «Мотор Січ» в плановому 2017 році порівняно з 2016 роком на 2221,07 тис. грн.

Отже, як висновок, ПАТ «Мотор Січ» буде доцільно на 2017 рік здійснити витрати на запланованому рівні, що дасть змогу підприємству отримати їх економію, наростити обсяги діяльності та згенерувати додаткові фінансові ресурси, які потім можуть бути використані з більш ефективною віддачею.

Висновки: У ринковій економіці управління витратами, як засіб досягнення високого економічного результату виробничо-господарської діяльності підприємства, орієнтується не тільки на їх зниження, а й спрямовується на зростання прибутку та забезпечення конкурентоспроможності підприємства. В сучасних умовах існує велика кількість методів розробки стратегій, які грунтуються або на ринковому підході 3 аналізом зовнішнього середовища, або на ресурсному - 3 аналізом внутрішніх сильних та слабких сторін підприємства. Нами було проаналізовано внутрішне середовище, а саме звітну фінансову інформацію підприємства, що дало змогу визначити оптимальний рівень затрат та спрогнозувати їх на 2017 рік, в подальших дослідженнях увага буде приділена одночасному аналізу, що базується ринкових та ресурсних методах, адже лише комплексний аналіз надасть змогу визначити оптимальну стратегію оптимізації витрат. 
Пошук можливих резервів зниження витрат виробництва доводить, що резерви - це не тільки зниження збитків при використанні ресурсів, але й невикористані можливості зниження витрат. Тому, скорочення розриву між досягнутим рівнем використання ресурсів та можливим рівнем, виходячи із оптимізації їх суми, сприятиме покращенню виробничого потенціалу машинобудівних підприємств, що було доведено на прикладі одного 3 провідних представників галузі «Мотор Січ». Саме науковим внеском авторів $€$ визначення оптимального рівня затрат для підприємства на основі використання методів аналізу внутрішньої фінансової звітності та визначення саме тих оптимальних затрат здійснення операційної діяльності при яких підприємство буде ефективно та прибутково працювати.

Таким чином, було виявлено те, що потрібно приділяти увагу механізму мінімізації витрат підприємства в загальній сумі чистого доходу, оскільки для ефективного використання виробничих ресурсів необхідні структурні зміни якісного характеру в сфері їх управління, як складової частини управління витратами в цілому. Наголошуємо саме на оптимізації витрат, а не скороченні їх обсягів, тобто слід виявити непродуктивні витрати, оскільки вони негативно впливають на фінансові результати та на ефективність господарювання в цілому.

\section{Лiтература:}

1. Азьмук, Л. Моделювання комбінаційних взаємозв'язків у системі «Витрати Випуск»: проблеми та шляхи їх розв'язання [Текст] / Л. Азьмук // Стратегія економічного розвитку України. - 2006. - № 6. - С. 231-234.

2. Бедринець М.Д. Ефективність діяльності суб'єктів підприємництва в сучасних умовах господарювання / М.Д. Бедринець // Бізнес Інформ. - 2013. - № 4. - С. 183-190.

3. Бойко В.В. Економічне обгрунтування мінімізації іммобілізованих коштів, вкладених у матеріали машинобудівного підприємства / В.В. Бойко, О.Ю. Будинська // Бізнес Інформ. - 2014. - № 3. - С. 255-260.

4. Волонцевич С.О. Розробка економічного механізму оптимізації структури граничних витрат на промислових підприємствах // Вісник Харківського національного університету ім. Каразіна. - Харків: ХНУ. - 2005. - № 668. - С. 77-79.

5. Машинобудування в Україні: тенденції, проблеми, перспективи / за заг. ред. чл.кор. НАН України Б. М. Данилишина. — Ніжин: Аспект-Поліграф, 2007. — 308 с.

6. Селезньова К.В. Аналіз використання експортного потенціалу машинобудівного комплексу України в контексті світових інтеграційних процесів / К.В. Селезньова // Економічний часопис - XXI. - 2010. - № 11-12. - С. 68-73.

7. Фідровська Н.М. Актуальні проблеми розвитку вітчизняних машинобудівних підприємств та шляхи їх вирішення / Н.М. Фідровська // Економіка і управління. - 2013. № 5. - C. 45-46.

8. Шарко В.В. Шляхи, основні напрямки та інструменти механізму інтенсифікації виробництва промислового підприємства / В.В. Шарко // Економіка і управління. - 2012. № 4. - С. 64-69.

9. Шейко I.А. Оцінка ефективності інноваційної діяльності машинобудівних підприємств: автореф. дис. к.е.н.: спец. 08.00 .04 / I.А. Шейко ; Нац. техн. ун-т «Харківський політехнічний інститут». - Х., 2013. - 24 с. 